\title{
IMPROVING STUDENTS' READING SKILL THROUGH INTERACTIVE APPROACH AT THE FIRST GRADE OF SMAN 1 MARE, BONE
}

\author{
Andi Herdiana Nur \\ Universitas Islam Negeri Alauddin Makassar \\ herdianaandi178@gmail.com \\ Hj. Djuwairiah Ahmad \\ Universitas Islam Negeri Alauddin Makassar \\ riaahmad@uin-alauddin.ac.id
}

\begin{abstract}
This paper aims to find out the improvement of the students' reading skill at the First grade of SMAN 1 Mare Bone through Interactive Approach method. This research used classroom action research (CAR) which was conducted to solve the students' problem in English reading. The Classroom Action Research (CAR) was done based on Kemmis and McTaggart's design.the researcher did two cycle in which each cycle consists of planning, acting, observing, and reflecting. The finding of the research indicated that the implementation Interactive Approach was successful since the criteria of success were achieved. The first criterion was $70 \%$ of students could pass the target score 70 based on the KKM. The finding showed that 74.57 of students had already achieved the target score. besides, the second criterion was the students who become more active involved in teaching learning process. the result of observation checklist showed that through Interactive Approach method, the students were more creative confident in the classroom especially reading activity. Based on the finding mentioned above, the researcher suggest that English teacher could implement Interactive Approach method in teaching reading in order to improve students in learning Englsih reading.
\end{abstract}

KEYWORDS: Students' Reading Skill, Interactive Approach.

\section{A. INTRODUCTION}

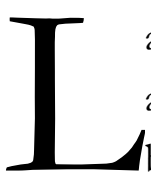

anguage is the most important aspect in human interaction. People communicate and interact with others by using the language. In a big community, English has become international language. Most of the community in the whole the world use English in order to communicate with others who have different language. Therefore, English teaching is very important to be taught and learned by students.

Teaching English for Senior High School, especially in reading class for the first grade, conveys the competence of identifying ideational meaning in the text, identifying interpersonal rhetoric in the context, and reading loud the text. But it is not easy to implement reading competence to students. Teacher face some problems in teaching English especially in reading comprehension. For instance the teaching method often makes students bored, the student are not motivated to learn since they have limited opportunity to express their idea. The approach of teacher to the students is not 
compatible and sustainable because teacher has limited knowledge of it, the facility is not proper.

The same condition happened in SMAN 1 Mare. There were many problems that appear in the teaching learning English, such as limited understanding on vocabulary, also motivation and interest of students learning English are still low. Then, the four language skills (listening, speaking, reading, and writing) of students are still unsatisfactory. Reading is one of the lowest among the four language skills. It can be proved by the mean score of reading 50. That mean score does not achieve the Standard Minimum Score (KKM) that is 70.

The students got low score in reading because they could not answer the text well. Especially in narrative text, it contains many difficult vocabularies and difficult to understand the mind behind the text. So, that's why they have to be given a good mainstay method to overcome it.

However, at least the problems can be minimizing by applying interesting way of teaching and learning model. The researcher should be creative to make a condusive classroom. Many techniques, methods, and models in teaching English can be applied in teaching learning process. The researcher could select ones which is compatible with the situation and condition of the students need and classroom, one of the learning methods is Interactive Approach.

The reason why uses Interactive Approach because this approach is an appropriate approach that can be conducted for beginners, intermediate, and advanced learners, for example senior high school students. It uses the good side from the top-down approach that can support the needs of learners by attracting their assumprion about the meaning of the text based on their background knowledge and a good side from the bottom-up approach that might suit vocabulary needs learners by leading them in learning reading through single-direction to analyze text from small part like words. Through Interactive Approaach as the approach in teaching reading in senior high school, the researcher thinks students can be more attracted and learn reading better.

Through interactive approach in the classroom, the teacher can help to the students improve their reading skill by practicing both bottom-up and top-down model reading activities. In bottom-up model students are trainde to develop their vocabulary and knowledge of structure. In top-down model, students are trained to activate their background knowledge before reading to predict the text. So that, the implementation of interactive approach gives an opportunity to improve their reading skill and make the reading activities more effective because this model monotonous system and make students enjoy the learning process.

Furthermore, the research problem of this research was "To what extent students' reading skill can be improve through Interactive Approachat the First grade of SMAN 1 
Mare, Bone?". Then, the research objective was to find out can be improve studnets' reading skill through Interactive Approach at the first grade of X6 class of SMAN 1 Mare, Bone. In addition, this research was benefical partically in the context for the students (they can increase their score in reading), the teachers (they can provide an alternative contribution and information about the teaching method in reading English), and for further researchers (they can use the finding of this study as one of their references). Finally, this research was focused on students' reading skill at the First grade of SMAN 1 Mare, Bone.

\section{B. LITERATURE REVIEW}

A number of researchers had been conducted in order to improve students' reading skill through Interactive Approach. First, Hajriani (2005) conducted the research of The Application of the Interactive Approach to the Teaching of English Reading in College. She concluded that application of Interactive Approach to the teaching of English reading in college can improve the students' reading ability and ecourage them to read extensively and critically and therefore think independently.

Furthermore, Pradana Akbar (2011) conducted the research of The Effectiveness of Interactive Approach to Teaching Reading to Tenth Grade of SMAK N 1 Depok in the 2011/2012 Academic Year. He concluded that the use of Interactive Approach was effective in improving studnets' reading comprehension ability. It could be seen through the hypothesis test of study. The hypothesis which said "there is significant difference in the students' reading ability among the studnets who are taught by using the interactive approach and the studnets who are taught by using the Interactive Approach" was accepted.

It can be concluded thyat there were the researcher decided to use Interactive approach method in improving students' activity in reading class. Besides, the research has difference with previous finding above. Therefore, they need many exercises material to improve their reading. In this case, the teachers are expected to give many exercises and use many kinds of techniques, method, or strategy in reading class and also the interesting model.

\section{Reading}

Reading is a passive skill which requires interactive process in comprehending the meaning in order to get information or ideas from written text. Understanding the meaning of the reading skill including the ability in reading from many experts who have different points of view is definitely important for the teacher of reading. It will be a useful knowledge to conduct a reading lesson in the classroom and a good reference to learn about how to deal with the reading skill more importantly. There are some defenitions about reading: 
1. Nunan (1999) stated that reading is sometimes viewed as a passive skill. It involves the processing of the generated ideas by others that are transmitted through language.

2. Eskey and Dubin (1986:12) stated that reading is a receptive language process. There is a process in which readers try to get more information from what is encoded by the author in the text in order to construct meaning from the text they read. Then, it can be understood that there is an interaction between a reader and a text in that reading process.

3. Alyousef (2006:64) stated that reading can be seen as an "interactive" process between a reader and a text which leads to automaticity or (reading fluency).

4. Harmer (1983) stated that reading is not passive skill. Reading is an active occuption. It involves many skill as guessing, predicting, checking, and asking oneself question.

5. Lewin (2003) stated that reading is understand the meaning of a text in reading activity, the reader makes interaction among eyes and mind to gain what the author extand.

6. Gebhard (2006) stated that Reading includes discovering meaning in print and script, within social context, through bottom-up (to comprehend written language, we rely on our ability to recognize words, phrases and sentences) and top-down processing (as well as on our background knowledge related to the content of what we are reading), and use of strategies and skill.

\section{Interactive Approach}

Interactive approach is a method or strategy given to the students to assist them have a better understanding on reading instruction by activating students' background knowledge (top down model) and word recognition exercises (bottom down model) used interactively.

\section{RESEARCH METHOD}

In this research, it was conducted a Classroom Action Research (CAR). It is a research conducted by the teacher who wants to make their students mastering the material. Commonly, Classroom Action Research is an effective media in improving the quality for English teachers' performance in instruction as well as students' achievement in learning English in the classroom. Kemmis and McTaggart in Jusman stated that CAR activities involve repeated cycles, each consisting of planning, acting, observing, and reflecting. The result of one cycle is used to determine the need for the following cycle, until the problems get solved by the strategy. For more detail information of the four components, the explanation are as below.

1) Plan

Plan is a step to prepare the classroom instructional strategy to be developed in the study to solve the instructional problems. The instructional strategy has been selected based on the belief that the strategy can theoretically solve the problems. It is strategy that 
becomes the focus of study, to be prepared, to be tried out, to be revised, to be tried again until it proves effective to solve the problems.

2) Action

Action is the second step after the planning step to implement the instructional strategy that has been planned. At this stage, the researcher has mastered the instructional scenario before starting the implementation in class. The researcher at this stage is not in the process of learning how to implement the plan, nor in the process of improving the quality of teachers' performance, but in the process of actually trying out the strategy to test how much the strategy can solve the classroom problems. The teacher is recommended to collaborate with one or two other teachers of the same subjects. The collaborators observe the implementation of the plan to see how much the strategy can solve the classroom problems.

3) Observation

Observation is the process of collecting data indicating the success of the strategy in solving the classroom problems. The focus of observation is on data related to the criteria of success that have been decided.

4) Reflection

Reflection is the process of analyzing data to determine how far the data collected have shown the success of the strategy in solving the problem. Reflection also shows what factors support the success of the strategy or what other problems may occur during the implementation process.

The researcher identified that dependent variable was students reading skill and the independent variable was the Interactive Approach. The research of setting was started on september $10^{\text {nd }}$ until September $30^{\text {th }}$ 2016.this research last for more than six weeks. The researcher took SMAN 1 Mare, Bone as a place for this research which is located on Jl. Makmur No. 1, Padaelo Kec. Mare is one of districts in South Sulawesi which is located about $96.12 \mathrm{~km}$ from south of Makassar City. The participants of this research were students of X6 class of SMAN 1 Mare which consist of 35 students.

The research target of this research was The students' achievement and failure in doing the planned activities will be assessed by referring the criterion issued of SMAN 1 Mare, namely Kriteria Ketuntasan Minimal (Minimum Passing grade Criteria). Based on the minimum ability criteria in the school, the school decides that the minimum ability criteria that the students have to reach are 70 . A class can be said reach the standard value if $70 \%$ students have catched the minimum ability criteria.

The instruments of this research are both test and observation checklist. 


\section{FINDINGS AND DISCUSSIONS}

\section{The Result of the Observation in the First Cycle}

\begin{tabular}{|l|c|}
\hline \multicolumn{1}{|c|}{ Learning Process } & Percentage \\
\hline 1. The seriousness of students in learning process & $62 \%$ \\
\hline $\begin{array}{l}\text { a. Giving attention to the teacher's pexplanation and } \\
\text { instruction }\end{array}$ & $57 \%$ \\
\hline $\begin{array}{l}\text { b. Making comments or asking question about the text to } \\
\text { the teacher }\end{array}$ & $54 \%$ \\
\hline c. Giving attention to the friend's opinion & $62 \%$ \\
\hline $\begin{array}{l}\text { d. Making comment or asking questions about the text to } \\
\text { their friends }\end{array}$ & $54 \%$ \\
\hline 2. The enthusiasm of the students when doing tasks & $51 \%$ \\
\hline $\begin{array}{l}\text { a. Trying to understand the instruction by using various } \\
\text { learning aids ( dictionary, book, text, ect., asking their } \\
\text { stduents or their friends whenever they do not } \\
\text { understand ) }\end{array}$ & 54 \\
\hline b. Taking notes whatever they think improtant & $60 \%$ \\
\hline c. Using various aids to accomplish their task, for example: \\
dictionaries, text books, work-sheets, etc
\end{tabular}

Based on the table of observation above, the students' responses was not maximal. There were stil some descriptors which must be improved. Beside that, there were also some descriptors that did well even though they still needed to be improved in the next cycle.

ased on the data above, there were some indicators that made it feel satisfied, because most of students did what the expect in applying Interactive Approach method. It was found that there were some indicators to the teachers' and instruction that raise score till $62 \%$ and taking note raised $54 \%$.

On the other side, the data above shows that were many indicators that needed improvement, they are: making comment or asking question about the text and asking to the teacher or to the friends, students' participation in asking question and the last in suggesting idea. 
2. Frequency distribution and percentage the students score of first cycle test

\begin{tabular}{|l|c|c|c|}
\hline Classification & Score interval & Frequency & Percentage (\%) \\
\hline $\begin{array}{l}\text { The students that exceed the } \\
\text { Standard Minimum Score } \\
(\mathrm{KKM}) .\end{array}$ & $\leq \mathbf{7 0}$ & 5 & $\mathbf{1 4 . 2 8 \%}$ \\
\hline $\begin{array}{l}\text { The students that achieved the } \\
\text { Standard Minimum Score } \\
(\mathrm{KKM}) .\end{array}$ & $\mathbf{7 0}$ & $\mathbf{3}$ & $\mathbf{8 . 5 8 \%}$ \\
\hline $\begin{array}{l}\text { The students was not achieve the } \\
\text { Standard Minimum Score (KKM) }\end{array}$ & $\geq \mathbf{7 0}$ & $\mathbf{2 7}$ & $\mathbf{7 7 . 1 4} \%$ \\
\hline \multicolumn{2}{|c|}{ Total } & 35 & $\mathbf{1 0 0 \%}$ \\
\hline
\end{tabular}

Based on the data, it indicated that the students' reading skill was not achieve the standard minimum score; it could be seen from the mean score. Even there were a little improvement in compare the result of pre cycle but it was not rose dramatically. From 35 students', 14.28 \% of students that exceed the Standard Minimum Score (KKM), $8.58 \%$ of students got achieve the standard minimum score and $77.14 \%$ of students was not achieve the standard minimum score $(\mathrm{kkm})$.

On the other side, there is an indicator of successfull students that has determined by the researcher namely: if $70 \%$ of students had been success in their reading skill achievement, it can be said that Interactive Approach method improved the students reading skill.

3. Indicator of Succesful students' reading skill in the first cycle

\begin{tabular}{|c|c|c|c|}
\hline Classification & Score interval & Frequency & Percentage \\
\hline Successful & $50-100$ & 18 & $51.43 \%$ \\
\hline Unsuccessfully & $0-50$ & 17 & $48.57 \%$ \\
\hline & Total & 35 & $100 \%$ \\
\hline
\end{tabular}

The data above showed that the successful criteria in the first cycle were not achieved yet. From the table above there were only $51.43 \%$ of students were classified success and the test were unsuccessful. Besides, the successful criteria were not achieved yet, that means the learning process was not maximal. Therefore, the researcher decided to improve the students' achievement in reading comprehension in the next cycle, the second cycle.

4. Comparison of the observation between the first cycle (C1) and the second cycle (C2)

\begin{tabular}{|c|c|c|c|c|}
\hline \multirow{2}{*}{ Aspects } & \multirow{2}{*}{ Indicators } & \multicolumn{2}{|c|}{ Percentage } & \multirow[t]{2}{*}{ Change } \\
\hline & & C1 & $\mathrm{C} 2$ & \\
\hline $\begin{array}{c}\text { The } \\
\text { seriousness }\end{array}$ & $\begin{array}{l}\text { a. Giving attention to the teacher's } \\
\text { explanation and instruction }\end{array}$ & 62 & 68 & +7 \\
\hline
\end{tabular}




\begin{tabular}{|c|c|c|c|c|}
\hline \multirow[t]{3}{*}{$\begin{array}{l}\text { of students } \\
\text { in learning } \\
\text { process }\end{array}$} & $\begin{array}{l}\text { b. Making comments or asking } \\
\text { question about the text to the } \\
\text { teacher }\end{array}$ & 57 & 63 & +7 \\
\hline & $\begin{array}{l}\text { c. Giving attention to the friend's } \\
\text { opinion }\end{array}$ & 54 & 54 & \\
\hline & $\begin{array}{l}\text { d. Making comment or asking } \\
\text { questions about the text to their } \\
\text { friends }\end{array}$ & 62 & 63 & +1 \\
\hline \multirow{5}{*}{$\begin{array}{l}\text { The } \\
\text { enthusiasm } \\
\text { of thye } \\
\text { students } \\
\text { when doing } \\
\text { tasks }\end{array}$} & $\begin{array}{l}\text { a. Trying to understand the } \\
\text { instruction by using various } \\
\text { learning aids ( dictionary, book, } \\
\text { text, ect., asking their stduents or } \\
\text { their friends whenever they do not } \\
\text { understand) }\end{array}$ & 54 & 66 & +13 \\
\hline & $\begin{array}{l}\text { b. Taking notes whatever they think } \\
\text { improtant }\end{array}$ & 51 & 60 & +10 \\
\hline & $\begin{array}{l}\text { c. Using various aids to accomplish } \\
\text { their task, for example: } \\
\text { dictionaries, text books, work- } \\
\text { sheets, etc }\end{array}$ & 54 & 65 & +12 \\
\hline & d. Actively investigating the topic & 60 & 69 & +10 \\
\hline & $\begin{array}{l}\text { e. Actively having discussion with the } \\
\text { teachers and friend. }\end{array}$ & 51 & 57 & +7 \\
\hline \multirow{5}{*}{$\begin{array}{l}\text { Students' } \\
\text { participation }\end{array}$} & $\begin{array}{llll}\text { a. The students' participation in } \\
\text { asking question }\end{array}$ & 60 & 62 & +3 \\
\hline & $\begin{array}{llll}\text { b. The students' participation in } \\
\text { suggesting idea }\end{array}$ & 54 & 65 & +12 \\
\hline & $\begin{array}{llll}\text { c. The students' participation in } \\
\text { group work }\end{array}$ & 51 & 63 & +13 \\
\hline & $\begin{array}{l}\text { d. Students listen to his/her friends } \\
\text { opinion }\end{array}$ & 62 & 68 & +7 \\
\hline & $\begin{array}{l}\text { e. Students answer the question from } \\
\text { the teacher }\end{array}$ & 60 & 65 & +6 \\
\hline & Total Score & 792 & 888 & 108 \\
\hline & Mean Score & 22.62 & 25.37 & 3.08 \\
\hline
\end{tabular}

*note: C1 : First Cycle C2 : Second Cycle

From the table above, showed that there were some improvements of students' responses during the learning process. It made happy because most of the indicators for each aspect increased.

As for the first aspect, all the indicators performed well. In the first indicators in this aspect, $62 \%$ of students listen to the teacher' explanation and instruction. It means that the indicators increased $7 \%$ because the score changed from $68 \%$ in the first cycle to $62 \%$ in the second cycle. The next was for the second indicator $63 \%$ of students' making a comment or asking question about the text. It increased $7 \%$ because the score changed 
from $57 \%$ to $63 \%$. The third indicator, $54 \%$ of students give an attention to the friends' opinion.. The last in the fourth indicator, $62 \%$ of students make a comments or asking question about the text to their friends. The percentage increased $1 \%$, because the score changed from $62 \%$ to $63 \%$.

For the second aspect, all indicators increased. The first indicator increased from 54 $\%$ to $66 \%$ of students trying to understand the instruction by using various learning aids. For the second indicator it showed improvement from 51\% to $60 \%$. The next for the third indicator, instead of $54 \%$ in the first cycle, in the second cycle $65 \%$ of students using various learning aids to accomplish their task, for example: dictionaries, text book, worksheet, etc.

The last for the third aspect, similar with the previous aspects, the same case happening this aspects. The first indicator increased $10 \%$ from $60 \%$ to $69 \%$. The second indicator increased $7 \%$ from $51 \%$ in the first cycle to $57 \%$ in the second cycle. While in the third indicator, it showed a significant from $60 \%$ to $62 \%$. The last of fourth and the fifth indicator, both of them were increased. The former increased $13 \%$ from $51 \%$ to $63 \%$.

\section{Frequency distribution and percentage the students learning achievement of second cycle test}

\begin{tabular}{|l|c|c|c|}
\hline \multicolumn{1}{|c|}{ Classification } & $\begin{array}{c}\text { Score } \\
\text { interval }\end{array}$ & Frequency & $\begin{array}{c}\text { Percentage } \\
\mathbf{( \% )}\end{array}$ \\
\hline $\begin{array}{l}\text { The students that exceed the Standard } \\
\text { Minimum Score (KKM). }\end{array}$ & $\leq \mathbf{7 0}$ & $\mathbf{2 6}$ & $\mathbf{7 4 . 2 8 \%}$ \\
\hline $\begin{array}{l}\text { The students that achieve the Standard } \\
\text { Minimum Score (KKM). }\end{array}$ & $=70$ & $\mathbf{9}$ & $\mathbf{2 5 . 7 1 \%}$ \\
\hline $\begin{array}{l}\text { The students was not achieve the Standard } \\
\text { Minimum Score (KKM) }\end{array}$ & $\geq \mathbf{7 0}$ & - & - \\
\hline \multicolumn{1}{|c|}{ Total } & 35 & $\mathbf{1 0 0 \%}$ \\
\hline
\end{tabular}

Based on the data above, it was indicated that, there was a significant improvement of the students' achievement in comprehension. The data of the mean score showed that the students' learning achievement was exceed the Standard Minimum Score (KKM). There were $74.28 \%$ of students got exceed the Standard Minimum Score (KKM) and 25.71\% achieved the Standard Minimum Score (KKM) and none students that achieved the Standard Minimum Score (KKM). For more details information about the improvement of students achievement in reading comprehension from the first cycle until the second cycle. 
6. The distribution of score frequency and percentage after teaching and learning process of cycle I (C1) and cycle 2 (C2)

\begin{tabular}{|l|l|l|l|l|l|}
\hline & $\begin{array}{l}\text { Score } \\
\text { Interval }\end{array}$ & \multicolumn{2}{l|}{ Frequency } & \multicolumn{2}{l|}{ Percentage } \\
\hline Classification & C1 & C2 & C1 & C2 \\
\hline $\begin{array}{l}\text { The students that exceed the } \\
\text { Standard Minimum Score } \\
\text { (KKM). }\end{array}$ & $\leq 70$ & 5 & 26 & $14.28 \%$ & $74.28 \%$ \\
\hline $\begin{array}{l}\text { The students that achieved the } \\
\text { Standard Minimum Score } \\
\text { (KKM). }\end{array}$ & $=70$ & 3 & 9 & $8.57 \%$ & $25.71 \%$ \\
\hline $\begin{array}{l}\text { The students that was not achieve } \\
\text { the Standard Minimum Score } \\
\text { (KKM). }\end{array}$ & $\geq 70$ & 27 & - & $77.14 \%$ & - \\
\hline
\end{tabular}

The table above showed that there were a significant improvement of the students' achievement in reading comprehension test from the first cycle until the second cycle. The data showed that there were $74.28 \%$ got exceed the Standard Minimum Score (KKM) and 25.71\% was achieved the Standard Minimum Score (KKM). In comparing with the first cycle $14.28 \%$ of students got exceed the Standard Minimum Score (KKM) and $8.57 \%$ achieved the Standard Minimum Score (KKM). Morever, based on the data, in the first cycle most of students was not achieve the Standard Minimum Score (KKM), there were $77.14 \%$ of students in that classification. Nevertheless, in the second cycle the percentage of students who was not achieve the Standard Minimum Score (KKM) no one students.

\section{Indicator of Succesful student's comprehension of the second cycle}

\begin{tabular}{|c|c|c|c|}
\hline Classification & Score Interval & Frequency & Percenatge \\
\hline Succesful & $50-100$ & 25 & $71.42 \%$ \\
Unsuccessfully & $0-50$ & 18 & $51.43 \%$ \\
\hline & Total & 43 & $111.43 \%$ \\
\hline
\end{tabular}

Based on the successful indicator above it could be concluded that the successful criteria in the second cycle had been achieved. There were $71.42 \%$ of students had reached the successful criteria. It means that Interactive Approach method improved the students reading comprehension since in the second cycle there were more than $70 \%$ of students had reached the successful criteria. It has passed the criteria that had been determined by the researcher.

In this research, it found that the students' comprehension improved after taught through Interactive Approach. It is indicated by the result of the first cycle was 2099 with 
the mean score 59.97 and the second cycle was 2610 with the mean score 74.57. It means that Interactive Approach is one of effective ways to improved the students' reading skill. So it was clear that Interactive Approach method done through interactive approach contributed to their reading skill enhancement. Therefore, it was concluded that Interactive Approach method in teaching reading could improve the students' reading skill. It was proved from by result of the research that students was the standard minimum scores (KKM) after giving a treatment than before giving the treatment.

\section{E. CONCLUSION AND SUGGESTION}

Based on the result of data analysis, it inferred teaching reading through interactive approach method actually passed KKM and some passed over it. It can be proved through several data such as a test in cycle I and cycle II. The result of test in cycle I showed that the students' mean score was 59.97 and the result of test in cycle II showed that the students mean score was 74.57 students who passed the KKM, so it showed the significant improvement in teaching reading through interactive approach method.

As the result of the study interactive approach was effectived to improve the students' reading skill, it is suggested the following things:

1. For the teacher, it is suggested to creatively find some interesting method which can motivate students in learning and are effective to teach English.

2. It is suggested to the English teacher to apply this interactive approach as one alternative teaching and learning process.

3. Teacher should be creative to choose the materials for teaching of Reading such as through interactive approach.

4. The teacher should be more creative and innovative to choose strategy in teaching English expecially narrative text. So that the studnets will be more interested, active and not boring.

5. The teacher should be give a motivation, support and guidance to the students in learning English.

\section{REFERENCES}

Abraham, Paul. (2002). T T Skilled Reading: Top-down, bottom-up. Field Notes, 10 (2). Nov 1, 2004.

Alyousef, H. S. (2006). Teaching Reading Comprehension to ESL/EFL Learners. Journal of Language and Learning.Vol. 5, No. 1, 2006.

Arikunto, S. (2006). Research Methods. Jakarta: Rineka Cipta.

Arikunto, S., Suhardjono \& Supardi (2008). Penelitian Tindakan Kelas. Jakarta: Bumi Aksara 
Alderson, J. C. and A. H. Urquhart (Eds) (1989). Reading in a foreign Language. London: Longman.

Brown, D.H. (2001).Teaching by Principles (Second Ed). London: Pearson Education.

Brown, D.H.(2004) Language Assessment Principles and Classroom Practice. London: Pearson Education.

Carrel, Patricia and Silberstein (1987) A Scema, Theory and ESL Reading pedagogy, methodology in Tesol: A book of Reading. USA Newbury House.

Depdikbud.(1985) Garis-Garis Besar Pengajaran Bahasa Inggris. Jakarta: Departemen Pendidikan dan Kebudayaan.

Eskey, D.E., and Dubin, F. (1986). Theoretical Foundations in Teaching Reading for Academic Purposes. Massachusetts: Addison-Wesley Publishing Company.

Eskey, D.E., \& Grabe, W. (1998). Interactive models for second language reading: Perspectives on instruction. In Morales, Katrina N.S. 2010. Promoting the Reading Comprehension of Freshmen Engineering Students through an Interactive Approach to Content-Based Materials. Philippines ESL Journal, Vol. 5, July 2010.

Farris, Pamela J. and Carol J. Fuhler (2004). Teaching Reading: A balanced Approach for today's classroom. New York: McGraw-Hill.

Gebhard, Jerry G.(2006). Teaching English as a foreign language or second language. Michigan: The University of Michigan press.

Grabe, W. (1998). Reassessing the term "interactive". In interactive approaches to second language reading, P.L. Carrel, J.Devine and D.E.Eskey (Eds.), 56-70. $\quad$ Cambridge: Cambridge University Press.

Grellet, Francoise (1986). Developing Reading Skill: A Practical Guide to Reading Comprehension Exercise. Cambridge: Cambridge University Press, 1986.

Harmer, J. (1983). The Practice of English Language Teaching. New York: Longman.

Harris, J. Albert, at al. (1980).How to Increase Reading Ability. New York: Harper Collins Publisher.

Hornby, A.S.(1994). Oxford Advanced Learner's Dictionary of Current English. Fourth Edition. Oxford: Oxford University Press.

Hajriani.(2005) The Application of the Interactive Approach to the Teaching of English Reading in College. Thesis. Makassar: English Departement of FBS UNM.

Heremy. J.(1991). The Practice of English Language Teaching. New Addition. New York: Longman.

Jusman,(2014) Improving Students' Speaking Ability through Describing Pictures at the Second Year Students of MTS As'adiyah kampung Baru Bone. Thesis of UINAM.

Kemmis, S. \& McTaggart, R. (1992).. The Action Research Planner. Victoria: Deaken University Press. 
Andi Herdiana Nur \& Hj. Djuwairiah Ahmad, Improving Reading Skill ...

McDonough, Jo \& Christopher, Shaw.(2003). "Materials and Methods in ELT: A Teacher's Guide)", New Jersey, Blackwell Publishing.

Kember, David.(2000) Action Learning and Action Research. London: Kogan Page Limited.

Kustaryo, S.(1998) Reading Technique for College Student. Departement Pendidikan dan Kebudayaan.

Lewin, Larry.(2003) Paving the Way in Reading and Writing: Strategies and Activities to SupportStruggling Students in Grades 6-12. San Francisco: Jossey- Bass.

Mabruroh. (2011)Improving Reading Comprehension Through Comprehension Monitoring Strategy of The Seventh Grade Students of SMA Negeri 8 Makassar. A Thesis of UNM..

Maxwell Martha J. (2000). Skimming and Scanning Improvement. Section 2 Exercises. Berkeley: McGraw-Hill Book Company.

McDonough, Jo and Christopher Shaw,(2003). Material and Method in ELT second edition, Oxford: Blackwell Publishing.

Miles, M. B. \& Huberman, A. M.(1984). Qualitative Data Analysis : A sourcebook of New Methods. California; SAGE publication Inc.

Nunan, D. (1999). Second Language Teaching \& Learning. Boston: Heinle \& Heinle.

Nuttall, Christine (1989).. Teaching Reading Skills in a Foreign Language 5th Edition. Oxford: Heinemann.

Rahman, Md. Hamidur. (2004). An Evaluation of the Teaching of Reading Skills of English.

Rajshahi: University of Rajshahi.

Ramelan. (1992).The Use of Word Square to Improve Reading Comprehension in Narrative Materials. Thesis. Makassar: English Departement of FBS UNM.

Cohen, L., Manion, L., \& Morrison K. (2000).Research Methods in Education (5th Edition). London: Routledge Falmer.

Thinker and Collogh. (1975).Teaching Elementary Reading. New Jersey: Harper Colling Publisher.

Smith, J. Richard \& Johnson. D. Dale.(1980). Reading Instruction for Today's Children. United States of America: Prentice Hall, Inc.

Ur, Penny. (1996). A Course in Language Teaching; Practice and Theory. Cambridge: Cambridge Univ. Press, 1996.

Vacca, Jo Anne L. et al.(2006). Reading and learning to read. Boston: Allyn \& Bacon.

Whorter, Kathleen. (1992).Efficient and Flexible Reading. Thirds. New York: Haspercollins Publisher

W. J. Best,(1970). Research in Education. New Jersey: Prentice Hall. 